\title{
Comparison of Percutaneous Nephrolithotomy Procedures Performed for Simple and Complex Renal Stones
}

\author{
Basit ve Kompleks Böbrek Tașları İcin Yapılan Perkütan Nefrolitotomi Ișlemlerinin \\ Karșılaștırılması
}

\author{
Kerem Taken', Sait Yamiș ${ }^{2}$, Kürșat Çeçen ${ }^{3}$, Recep Eryılmaz ${ }^{4}$, Mustafa Güneș ${ }^{1}$ \\ ${ }^{1}$ Department of Urology, Yüzüncüyll University School of Medicine, Van, Turkey; ${ }^{2}$ Department of Urology, Bağlar Hospital, Diyarbakır, Turkey; \\ ${ }^{3}$ Department of Urology, Kafkas University School of Medicine, Kars, Turkey; ${ }^{4}$ Department of Urology, Tatvan State Hospital, Tatvan, Bitlis, Turkey
}

\begin{abstract}
AIM: To compare the percutaneous nephrolithotomy procedures performed for simple and complex kidney stones.

METHODS: In this retrospective study, 268 renal stones operated using percutaneous nephrolithotomy, between January 2011 and March 2014, were evaluated. Operations were performed for upper /middle calyx stones and lower calyx stones larger than $2 \mathrm{~cm}$ and $1.5 \mathrm{~cm}$, respectively. Success rate, complications, number of percutaneous entry, operation time, and hospital stay were evaluated. The results of the operations of the simple and complex stones were compared.
\end{abstract}

RESULTS: Percutaneous nephrolithotomy was performed in 268 renal units in $186(73.5 \%)$ male and $67(26.5 \%)$ female, with a mean age of $43.1 \pm 12.15$ (13-78) years. There were 169 (63\%) simple and 99 (37\%) complex stones. Mean stone burden was $340 \mathrm{~mm}^{2}$ (30-760). Mean preparation time for surgery was 27.2 (20-50) min. and mean operation time was 90.4 (40-170) min. Blood transfusion was required in 35 cases. Open surgery was needed in two patients due to perioperative bleeding. Colon injury occurred in one patient.

Double-J catheter was inserted in 13 patients. Stone clearance rate in simple and complex stones was $78 \%$ and $40 \%$, respectively $(p<0.01)$. The rate of success was $87 \%(n=232)$ in all patients.

CONCLUSION: The rate of patients requiring additional treatment and the rate of failure are significantly higher in complex stones than in simple stones. However, percutaneous nephrolithotomy is an effective and safe method providing high success rates, shorter hospital stay, and acceptable complication rates.

Key words: complications; kidney; nephrolithotomy; outcome assessment; percutaneous; stone

\section{ÖZET}

AMAÇ: Basit ve kompleks böbrek tașları için yapılan perkutan nefrolitotomi ișlemlerinin bulgularını karșılaștırmak.

Yard. Doç. Dr. Kerem Taken, Yüzüncüynl Üniversitesi Tip Fakültesi, Üroloji Anabilim Dal, Van, Türkiye Tel.05058396126Email.www.takenyyu@yahoo.com

Received: 16.05.2014 • Accepted: 05.08.2014
YÖNTEM: Bu retrospektif çalıșmada, Ocak 2011 ve Mart 2014 arasında perkutan nefrolitotomi ile ameliyat edilen 268 böbrek tașı incelendi. Ameliyatlar, iki cm den büyük üst ve orta pol böbrek tașlarına ve 1,5 cm den büyük alt kaliks tașlarına ișlem yapıldı. Hastalar bașarı oranı, komplikasyonlar, perkütan giriș sayısı, ameliyat süresi, hastanede kalıș süresi açısından değerlendirildi. Basit ve kompleks böbrek tașları için yapılan ameliyatların bulguları karșılaștııldı.

BULGULAR: Perkutan nefrolitotomi 186 (\%73,5) erkek, 67 (\%26,5) kadın hastada, 268 renal üniteye yapıldı. Olguların idi. Yaș ortala-

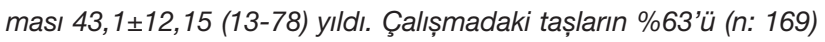
basit, \%37'si (n: 99) ise kompleksti. Ortalama taș yükü 340 mm² (30-760) olarak hesaplandı. Cerrahi girișim için ortalama hazırlık süresi 27,2 (20-50) dakika, ortalama operasyon süresi 90,4 (40-170) dakikaydı. Otuz beș olguda kan transfüzyonu yapılırken, iki hastaya ise intra-operatif kanamadan dolayı açık cerrahi yapıldı. Bir hastada kolon yaralanması yașandı.

On üç hastaya ise double-J kateter konuldu. Taștan tamamen temizlenme oranı, basit izole tașlarda \%78, kompleks tașlarda \%40 idi $(p<0.01)$. Tüm olgular incelendiğinde, \% 87'sinin ( $n: 232)$ bașarıyla sonuçlandığı gözlendi.

SONUÇ: Kompleks tașı olan hastalarda ek tedavi ihtiyacı ve tedavi bașarııızığı oranı belirgin olarak daha yüksektir. Ancak, yüksek bașarı oranı, kısa hastanede kalıș süresi ve Kabul edilebilir komplikasyon oranlarıly, perkutan nefrolitotomi etkin ve güvenli bir yöntemdir.

Anahtar kelimeler: komplikasyonlar; böbrek; nefrolitotomi; sonuç değerlendirmesi; perkütan; taș

\section{Introduction}

Percutaneous nephrolithotomy (PCNL) causing lower morbidity and shorter hospital stay has replaced open surgery in the treatment of large kidney stones and has been the method of choice for the treatment of kidney stones larger than $2 \mathrm{~cm}$ since $1980^{1}$.

Advances in extracorporeal shock wave lithotripsy (ESWL) and endourology have greatly reduced indications for open surgery ${ }^{1}$. In addition, latest technological advances have increased the success rates of PCNL 
and also the modifications in the procedures of PCNL have significantly reduced morbidity ${ }^{2,3}$. Meta-analyses have reported lower complication rates for PCNL and most of the complications are minor ${ }^{4}$.

In this study, we aimed to retrospectively analyze the percutaneous nephrolithotomy applications performed in our clinic and to evaluate them in the light of the current literature.

\section{Methods}

This retrospective study included the PCNL applications performed in 268 renal units between January 2011 and March 2014. The study complies with the Helsinki Declaration.

Prior to surgery, whole blood count (WBC), urine analysis and culture, prothrombin time (PT), partial thromboplastin time (PTT), international normalized ratio (INR), and hepatitis indicators (HIV, HBV, and $\mathrm{HCV}$ ) were evaluated.

Stone surface area was measured as $\mathrm{cm}^{2}$ by multiplying the longest diameter of the stone by its intersecting vertical diameter using direct urinary system graphy (DUSG). Preoperative evaluations were performed using computed tomography (CT) and intravenous pyelography (IVP). In the patients with positive urine culture, antibiotic therapy was started at least 1 week prior to the procedure.

Based on the results of PCNL, the cases were divided into three groups as (I) 'stone-free', (II) 'clinically insignificant residual fragments (CIRFs)', and (III) 'failed PNCL procedure'. CIRFs were described as non-obstructive and noninfectious stone fragments smaller than $4 \mathrm{~mm}$.

All the patients were operated using cystoscopy under general anesthesia at the lithotomy position. The procedure was initiated by inserting a ureteral catheter (5.0/6.0 Fr open-end ureteral catheter) and the catheter was fixed to the 16/18 Foley catheter which had been previously inserted. Then, the patient was placed in the prone position. At this position, the kidney stones were detected under C-arm fluoroscopy (SireMobil Compact, Siemens, Germany). The anatomy of the renal collecting system was illustrated by retrograde pyelography. The calyxes were entered at a $90^{\circ}$ angle using an $18 \mathrm{G}$ percutaneous access needle (Microvasive) under multi-planar C-arm fluoroscopy. A guide wire (Sensor guide wire, Microvasive) was inserted through the needle. Dilatation was achieved over the guide wire using filiform dilators and care was taken to advance the guide wire as far back into the ureter as possible. A percutaneous port was created by performing $30 \mathrm{~F}$ dilatation over the guide wire using Amplatz dilators and a ureteral access sheath was inserted. The stones were fragmented using a 26F rigid nephroscope (Wolf, Germany) and pneumatic lithotriptor (VibrolithElmed, Ankara, Turkey). The fragments were removed through the sheath by using grasping forceps. Following the removal of the fragments, an 18 Fr nephrostomy tube was inserted. The integrity of the system and the insertion of the tube were checked by delivering opaque medium through the nephrostomy tube under fluoroscopy. At the end of the procedure, the ureteral catheter was left as fixed to the Foley catheter.

The nephrostomy tube was removed after clamping for 3-12 $\mathrm{h}$ and the ureteral catheter was removed on postoperative day 1 . The tube was clamped in the patients presenting with no clinically significant rest stones $(>4$ $\mathrm{mm}$ ) on DUSG and with bright urine. In these patients, the clamp was removed after $2-4 \mathrm{~h}$. The tube was removed in the patients detected with no significant residue $(>50 \mathrm{cc})$. A double-J catheter was inserted in the patients with prolonged urinary leakage $(>24-48$ h). Additional treatments including PCNL, ureterorenoscopy (URS), and extracorporeal shockwave lithotripsy (ESWL) were performed in case where needed. At postoperative third month, all the patients were evaluated using IVP or CT. CIRF stones were accepted as small $(<4 \mathrm{~mm})$, asymptomatic, non-obstructive and noninfectious stone fragments, whereas rest stones were accepted as the fragments larger than $4 \mathrm{~mm}$. Successful PCNL outcome was defined as being stone free or having CIRF stones.

Statistical differences and correlations were analyzed using Chi-square test and Spearmen's Correlation Coefficient. A $p$ value of $>0.05$ was considered significant.

\section{Results}

A total of 268 renal units in 253 patients were treated by PCNL. Isolated stones were detected in 238 (94.1\%) and bilateral stones were detected in 15(5.9\%) patients. There were $186(73.5 \%)$ male and 67 (26.5\%) female patients with a mean age of $43.1 \pm 12.15$ (13$78)$ years. Twenty-seven (10.6\%) patients had a history of open renal surgery, 47 patients (18.5\%) had a history of ESWL at the same side, and $5(1.9 \%)$ patients had solitary kidney. 


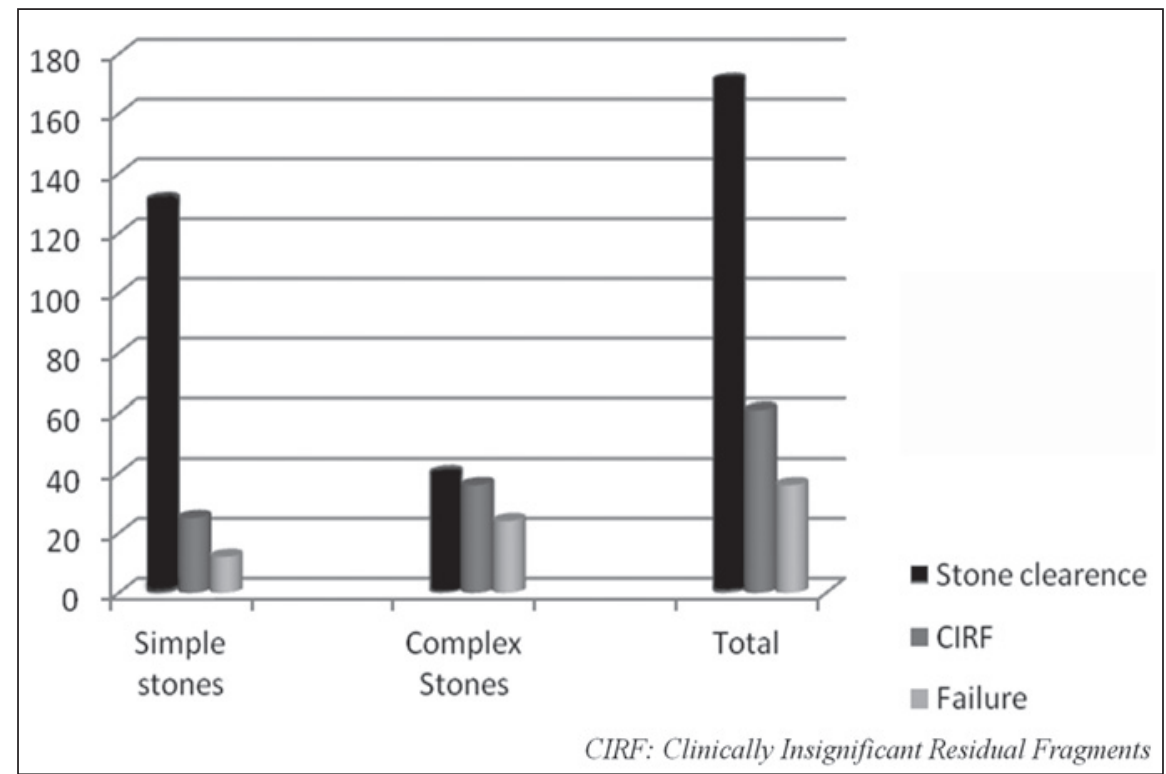

Figure 1. The success rates for simple and complex stones managed by percutaneous nephrolithotomy.

The stones comprised 169 (63\%) simple stones and 99 (37\%) complex stones. Of the simple stones, 80 (30\%) were localized in the renal pelvis, 65 (24\%) in the lower calyx, and 24 (9\%) in the upper calyx. Of the complex stones, $15(15 \%)$ were localized in pelvis and lower calyx, seven (7\%) in pelvis and middle calyx, $10(10 \%)$ in pelvis and multi-calyxes, and five (5\%) were coraliform stones. Mean stone burden was $340 \mathrm{~mm}^{2}$ (30-760). Of the 253 patients, subcostal percutaneous entry was performed in 249 (92.9\%) and intercostal entry was performed in 19 (7.1\%) patients. Single-port percutaneous input was sufficient in 246 patients $(92 \%)$, whereas a second percutaneous port was required in $22(8 \%)$ patients.

In the follow-up period, $64 \%(n=171)$ of the renal units were stone-free, $23 \%(\mathrm{n}=61)$ had CIRF stones, and PCNL failed in $13 \%(n=36)$. One of the patients with failed PCNL had solitary kidney. The additional treatments performed were as follows: Re-PCNL was performed in 11, ESWL in 14, and retrograde intrarenal surgery (RIRS) in eight patients. In three patients, open surgery was performed during the same surgical session due to bleeding $(n=2)$ and failed entry $(n=1)$. Successful outcome was obtained in all of these patients. No nephrectomy was performed in any patient.

Stone clearance rate was significantly higher in isolated simple stones ( $78 \%$ versus $40 \%$ ) than in complex stones $(\mathrm{p}<0.01)$. The rate of CIRF was $15 \%$ in simple and $35 \%$ in complex stones. The rate of patients requiring additional treatment and the rate of failure were significantly higher in complex stones than in simple stones. Figure 1 presents the success rates for simple and complex stones.

Mean preparation time for surgery was 27.2 (20-50) min. and mean operation time was 90.4 (40-170) min. Mean removal time for the nephrostomy tube was 2.7 (range, 1-5) days and mean hospital stay was 3.2 (range, 2-14) days. Following the PCNL procedure, blood transfusion was required in 35 patients. Open surgery was performed in two patients due to perioperative bleeding. Twenty-six patients had postoperative fever $\left(>38^{\circ} \mathrm{C}\right)$ and were treated by antibiotic therapy in the follow-up period. Resistant infection was detected in one patient and was treated in 14 days. Colon injury occurred in one patient and was treated by primary treatment. Prolonged urinary leakage was detected in 13 patients $24-48 \mathrm{~h}$ after the removal of nephrostomy tube. In these patients, a double-J catheter was inserted and then removed after 3 weeks. Figure 2 presents the complication rates according to stone groups.

\section{Discussion}

PCNL is a treatment method providing successful outcomes in transplanted kidneys, complex kidney 


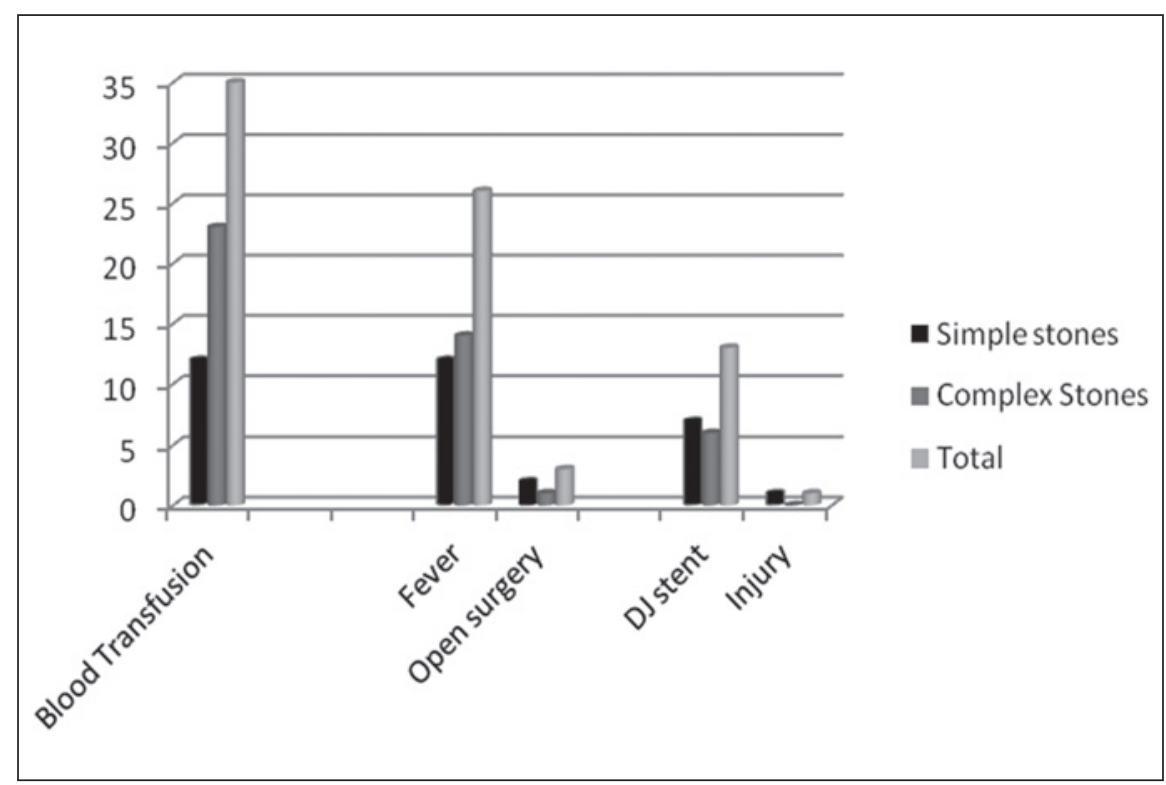

Figure 2. The complication rates of percutaneous nephrolithotomy procedures performed for renal stones.

stones, coraliform stones, isolated upper, calyceal, diverticular and ureteral stones. It is also preferred in children, older and overweight patients. Patients with orthopedic deformities and congenital renal anomalies such as horseshoe kidneys and ectopic kidneys are also managed with it ${ }^{5}$. First series of PCNL were reported by Alken and Wickheim in 1981 and the first largescale studies with more than 1,000 cases were reported in $1985^{6}$. However, the first large series of PCNL in Turkey was reported in the $2000 s^{7}$.

Success rate of PCNL ranges between $40-90 \%$ depending on the number and localization of the stones, chemical structure of the stones, and the experience of the surgeon ${ }^{8}$. The success rate of PCNL in Turkey ranges between $60-95 \%{ }^{9,10}$. In our study, $64 \%(n=171)$ of the renal units were stone-free, $23 \%(\mathrm{n}=61)$ had CIRF stones, and PCNL failed in $13 \%(\mathrm{n}=36)$. Therefore, the success rate was calculated as $87 \%$. Stone clearance rate of $78 \%$ in isolated simple stones was significantly higher than the rate $40 \%$ in complex stones $(p<0.01)$. Unquestionably, the rate of stone-free cases is likely to increase as the numbers of cases and the experience of the surgeons increase.

The rate of patients requiring additional treatment following PCNL is reported to be $10 \%{ }^{1}$. In our study, the rate of patients requiring additional treatment was $13.4 \%$.
Bleeding is one of the main complications during PCNL. Kessaris et al. reported the rate of bleeding requiring embolization following PCNL as $0.8 \%{ }^{12}$. In our study, two patients $(<1 \%)$ underwent open surgery due to perioperative bleeding. The rate of bleeding requiring blood transfusion during PCNL is reported to be between 14-23\% ${ }^{13,14}$. In line with the literature, $13 \%$ $(n=35)$ of our patients required perioperative blood transfusion due to bleeding.

Stone size is generally large in complex and coraliform stones. Kukreja et al. reported that stone size had no significant effect on blood loss but it increased the rate of blood transfusion ${ }^{13}$. In our study, the requirement of blood transfusion was significantly higher in patients with complex stones (26\%). This situation can be attributed to a number of factors including longer operation times caused by high stone burden, the injury caused by multiple entries, and the entries into the upper pole.

Hydropneumothorax is a common complication reported to occur in $0.7-1.7 \%$ of the patients treated by intercostal approach, which is the method of choice particularly for the treatment of upper calyceal stones ${ }^{9,15}$. In our study, no hydropneumothorax was observed and this can be attributed to the limited use of intercostal approach in our patients. Lee et al. reported that pelvic laceration occurred in $0.9 \%$, 
ureteral avulsion in $0.2 \%$, and urinoma formation in $0.3 \%$ of their patients and the stones slipped into the retroperitoneal space in $1 \%$ of their patients ${ }^{16}$. In these series, ureteral avulsion and pelvic laceration were surgically treated, whereas urinoma and stone slippage were treated by conservative therapy. Segura et al. reported that one $(0.1 \%)$ patient had ureteral laceration and another patient $(0.1 \%)$ had stone slippage due to ureteral perforation ${ }^{6}$. Also, parenchymal laceration occurred in $2(0.2 \%)$ patients during dilatation and it was treated by open surgery. In our study, no pelvic laceration or ureteral avulsion occurred in any patient. We consider that the rate of these complications is likely to increase as the number of patients treated with PCNL increase. In our series, only prolonged urinary leakage was observed in 13 (4.8\%) patients and the patients were treated using double-J catheters. The stents were removed three weeks later and no permanent fistula was observed during the follow-up at three months.

Taşkıran et al. conducted a single-center study with 533 cases and reported that $76.4 \%$ of the patients underwent single-port, $16.1 \%$ underwent double-port, $7.1 \%$ underwent three-port, and one underwent four-port input and no perioperative complication occurred in $92.9 \%$ of the patients ${ }^{17}$. In our study, single-port percutaneous input was sufficient in $92 \%$ $(\mathrm{n}=246)$ and double-port input was formed in $8 \%$ $(n=22)$ of the patients. Subcostal percutaneous entry was performed in $92.9 \%(\mathrm{n}=249)$ and intercostal entry was performed in $7.1 \%(n=19)$ of the patients. None of our PCNL procedures was performed using more than two ports. Mean operation time was reported to vary according to the experience of the surgeon. In our study, mean operation time was 90.4 (40-170) $\mathrm{min}$.

\section{Conclusion}

The rate of patients requiring additional treatment and the rate of failure are significantly higher in complex stones than in simple stones. However, PCNL is an effective and safe method providing high success rates, shorter hospital stay, and acceptable complication rates.

\section{References}

1. Turk C, Knoll T, Petrik A, et al. Selection of procedure for active removal of kidney stones. Guidelines on Urolithiasis, EAU 2014.

2. Ramakumar S, Segura JW. Percutaneous management of urinary calculi. Scientific World J 2004;4:296-307.

3. Davidoff R, Bellman GC. Influence of technique of percutaneous tract creation on incidence of renal hemorrhage. J Urol 1997;157:1229-31.

4. Labate G, Modi P, Timoney A et al. The percutaneous nephrolithotomy global study: classification of complications. J Endourol 2011;25:1275-80.

5. Wolf SJ, Clayman RV. Percutaneous nephrotolithotomy: What is its role in 1997? Urol Clin North Am 1997;24:43-58.

6. Segura JW, Patterson DE, LeRoy AJ, et al. Percutaneous removal of kidney stones: Review of 1000 cases. J Urol 1985;134:1077-81.

7. Yüksel MB, Kar A, Ciloglu M. The applicability of percutaneous nephrolithotomy in provincial state hospitals: the experience of the State Hospital of Mus in first 100 cases. Turkish Journal of Urology 2010;36:362-8.

8. Park J, Hong B, Park T, Park HK. Effectiveness of noncontrast computed tomography in evaluation of residual stones after percutaneous nephrolithotomy. J Endourol 2007;21:684-7.

9. Müslümanoğlu AY, Tefekli AH, Taş A, Çakır T, Sarılar Ö. Analysis of the first 100 cases of percutaneous nephrolithotomy in the learning curve. Turkish Journal of Urology 2004;30:339-47.

10. Erbin A, Berberoğlu Y, Sarılar Ö et al. Percutaneous nephrolithotomy: Our results of a single center analysis in 2300 cases. The Medical Bulletin of Haseki Training and Research Hospital 2014;52:1.

11. Segura JW. Percutaneous nephrolithotomy: Technique, indications, and complications; AUA Guidelines 1993;12:154.

12. Kessaris D, Bellman G, Pardalidis N, et al. Management of hemorrhage after percutaneous renal surgery. J Urol 1995;153:604-8.

13. Kukreja R, Desai M, Patel S, et al. Factors affecting blood loss during percutaneous nephrolithotomy: Prospective study. J Endourol 2004; 18:715-22.

14. Turna B, Umul M, Altay B et al. Effect of Stone burden on PNL outcomes. Turkish Journal of Urology 2006;32:500-5.

15. Yalçın V, Önal B, Çitgez $S$ et al. The complication rates and results of upper pole access in percutaneous nephrolithotomy cases. Turkish Journal of Urology 2007;33:191-5.

16. Lee WJ, Smith AD, Cubelli Vetal. Complications of percutaneous nephrolithotomy. AJR Am J Roentgenol 1987;148:177-80.

17. Taşkıran M, Tanrıverdi O, Sarığulları, et al. Our percutaneous nephrolithotomy experiences: a single center experience with 533 patients. The Medical Bulletin of Şişli Etfal 2012;46:193-8. 